https://doi.org/10.15407/ujpe65.9.794

L.A. BULAVIN,${ }^{1}$ V.YA. GOTSULSKYI, ${ }^{2}$ N.P. MALOMUZH,${ }^{2}$ A.I. FISENKO ${ }^{2}$

1 Taras Shevchenko National University of Kyiv, Faculty of Physics

(64/13, Volodymyrs'ka Str., Kyiv 01601, Ukraine; e-mail: bulavin221@gmail.com)

2 I.I. Mechnikov National University of Odesa

(2, Dvoryans'ka Str., Odesa 65026, Ukraine; e-mail: vygot@onu.edu.ua)

\title{
CRUCIAL ROLE OF WATER IN THE FORMATION OF BASIC PROPERTIES OF LIVING MATTER
}

\begin{abstract}
$A$ relation between the water properties and the behavior of aqueous solutions of albumin, the main protein component of human blood plasma, has been analyzed. The dependence of the $p H$ index of acid-base balance in aqueous albumin solutions on the albumin concentration is experimentally studied. It is shown that the temperature dependences of $\mathrm{pH}$ in biological solutions are determined by the properties of water, and the concentration ones by the concentration of a protein component. It is albumin that makes the main contribution to the pHs of blood and blood plasma, and it should be considered as a factor that maintains the equilibrium $p H$ value. It is shown that the most characteristic changes in the concentration dependences of the density and shear viscosity of human plasma occur at a protein concentration corresponding to the percolation threshold. A characteristic dimerization of albumin macromolecules is assumed to take place at the percolation threshold, which corresponds to the superposition on one another of heart-shaped medallions representing the spatial forms of albumin. The dependences of the effective radii of polyvinyl alcohol and albumin macromolecules on the solution temperature and concentration are demonstrated to be an indicator that water plays a decisive role in the formation of basic properties of biosolutions. In particular, it is responsible for the presence of an upper temperature limit of $42^{\circ} \mathrm{C}$ for the existence of living matter. The universal nature of the water influence manifests itself in that the water properties affect the behavior of both the classic PVA polymer and protein biomolecules.
\end{abstract}

Keywords: water, biological solutions, human albumin, $\mathrm{pH}$, characteristic temperatures, percolation.

\section{Introduction}

The water content in living matter is $60-75 \%$. Various forms of living matter had been arisen and had been developing for a long time in water of primordial oceans [1-3]. The existence of substantially dehydrated organisms is impossible. Furthermore, a human being can survive much longer without food than without water. All those facts testify to the crucial role of water for the functioning of various systems in living organisms. From a general viewpoint, it cannot be otherwise. The simplest living organisms had been developing in the primordial ocean. Their fragments were even simpler and were also formed under the influence of surrounding water. Therefore, it is the influence of water properties rather that the interac-

(C) L.A. BULAVIN, V.YA. GOTSULSKYI, N.P. MALOMUZH, A.I. FISENKO, 2020 794 tion between the organism fragments or their parts that played a crucial role in the evolution of living matter.

In this connection, let us dwell on the most important properties of water that have the greatest influence on various systems in living organisms. In so doing, we will take into account, in particular, that a human being can exist, if the functioning temperature of his/her internal organs falls within an interval of $32-42{ }^{\circ} \mathrm{C}[4,5]$. The existence of pure water in this interval is characterized by the following characteristic properties.

- Water molecules are connected with one another by $2.5-2.6$ hydrogen bonds on the average. Those bonds can form a spatial network.

- Due to hydrogen bonds, water molecules form clusters that exist during a relatively short time interval of an order of picoseconds. The clusters have

ISSN 2071-0194. Ukr. J. Phys. 2020. Vol. 65, No. 9 
an ice-like structure, i.e. water is not an unstructured liquid.

- Thermal excitations of clusters are responsible for the heat capacity of water. This parameter is two to three times as large as the heat capacity values for the majority of low-molecular liquids.

- In the vicinity of the normal physiological body temperature, the heat capacity of water at a constant pressure has a minimum value, which favors the stabilization of thermal processes in the body.

- The dielectric permittivity of water remains substantial $(\varepsilon>75)$, which stimulates the dissociation of externally introduced salts and acids, as well as surface amino acids that enter the composition of proteins.

- Water molecules are characterized by a low but extremely important degree of self-dissociation, which corresponds to the acid-base balance $\mathrm{pH} \approx 7.0$. As a result of the self-dissociation, there arise a small number of extremely mobile $\mathrm{H}^{+}$cations, which radically affect the properties of admixture proteins.

- Water is characterized by specific temperature dependences of its dielectric relaxation time and compressibility. In the vicinity of $42{ }^{\circ} \mathrm{C}$, the former tends to the free rotation time and the latter has a minimum.

A direct relation between the properties of water and the functioning of living organisms or proteins has been demonstrated for the first time in works $[6,7]$. In particular, it was shown that, at the temperature $T_{D} \approx 42{ }^{\circ} \mathrm{C}$, the crystal-like character of the thermal motion of water molecules transforms into an argon-like one, which corresponds to the absence of clustering. This temperature is known to be the upper limit for human life or, in terms of the existence of some proteins, the temperature of their denaturation [8-10]. In effect, this means that a long evolution of primitive proteins in the ocean has led to the adjustment of their most important properties to those of water, in particular, to the temperature at which the character of thermal motion of water molecules changes. The manifestations of some other properties of water in the behavior of proteins and living matter were discussed in work [11]. A certain onesidedness of those results consists in that the structure of proteins in living organisms was taken into account rather superficially in the cited works.

The aim of this work was to analyze the relation between the properties of water and the behavior of one of the simplest proteins, albumin, in aqueous solutions. According to work [12], an isolated albumin macromolecule looks like a heart-shaped medallion about $80 \AA$ in diameter and about 30 Ain thickness. It consists of three domains, each of which has two subdomains. In their turn, the subdomains consist of two interconnected $\alpha$-helices formed by amino acid sequences. When amino acids are dissolved in water and enter the near-surface layer of an albumin macromolecule, they begin to interact with the aqueous environment. In so doing, some of them dissociate and send $\mathrm{H}^{+}$ions into the aqueous medium, whereas their other part, which includes molecular groups with a nitrogen atom, can attach $\mathrm{H}^{+}$. As a result, the $\mathrm{pH}$ of the aqueous albumin solution should substantially change with the growth of both the albumin concentration and the temperature. The addition of acids or alkali to the solution invokes a further redistribution of $\mathrm{H}^{+}$ions, and there appear electric double layers of different polarities. When albumin is dissolved in water, the character of bonds between the domains and subdomains also changes, which gives rise to certain changes in the size of albumin macromolecules in the solution depending on the solution temperature, concentration, and $\mathrm{pH}$.

In this work, we present the results of certain experiments and discuss their physical nature.

\section{The $\mathrm{pH}$ of Aqueous Albumin Solutions and Blood Plasma}

In work [13], it was found that the temperature dependences of the $\mathrm{pH}$ for water, blood, and blood plasma are linear functions in the temperature interval $25{ }^{\circ} \mathrm{C}<T<50{ }^{\circ} \mathrm{C}$ (see Fig. 1). Furthermore, the slopes of the lines for blood and blood plasma are rather close to the corresponding parameter for pure water. This fact undoubtedly testifies that the properties of water are responsible for the temperature dependences of the blood and blood plasma parameters. But a direct origin of the difference between the $\mathrm{pH}$ values for water, on the one hand, and for blood and its plasma, on the other hand, remained unclear.

To explain this phenomenon, we present the following considerations. First, let us take into account that the $\mathrm{pH}$ of blood is almost entirely determined by the $\mathrm{pH}$ of blood plasma, and the role of erythrocytes is not substantial. Second, blood plasma can be considered as an aqueous solution of proteins with their 


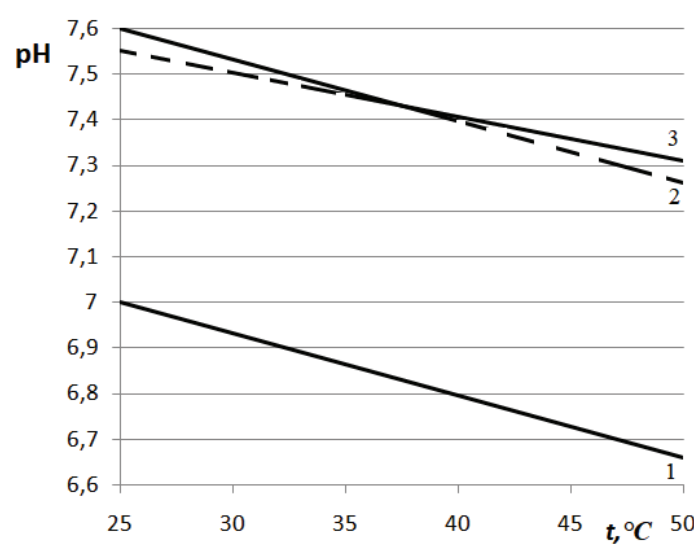

Fig. 1. Temperature dependences of $\mathrm{pH}$ for pure water $[13,14]$ (1), whole blood [13] (2), and blood plasma [13] (3)

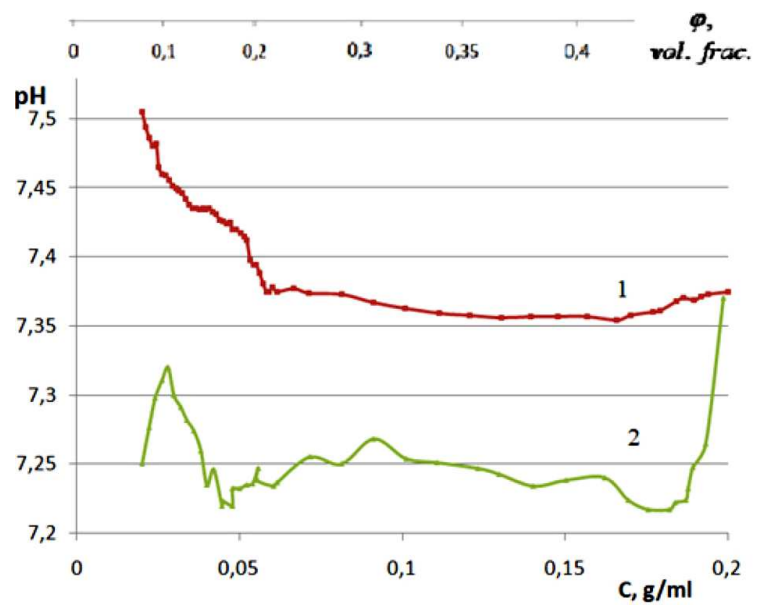

Fig. 2. Dependences of the $\mathrm{pH}$ index of the aqueous human albumin solution on the albumin concentration. The lower axis corresponds to the mass concentrations of albumin $\left(\mathrm{g} / \mathrm{cm}^{3}\right)$, and the upper axis to its volume concentrations. Curves 1 and 2 exhibit experimental data obtained at temperatures of $19^{\circ} \mathrm{C}$ and $37^{\circ} \mathrm{C}$, respectively

weight concentration of $7-8 \%$. Among the latter, the most significant role is played by the macromolecules of albumin (up to $65 \%$ of the protein component in blood plasma), globulins (25\%), and fibrinogen (up to $0.4 \%$ ). The protein components of blood plasma play an important role in the formation of plasma properties; first of all, these are its density and shear viscosity.

Therefore, we may assume that the $\mathrm{pH}$ difference between blood plasma and water emerges owing to the presence of albumin macromolecules. Additionally, let us take into account that albumin macro- molecules consist of certain amino acid sequences. Those sequences are combined into $\alpha$-helices, and the latter into subdomains and domains. Amino acid residues in the near-surface layers of albumin macromolecules interact with surrounding water and can partially dissociate into a hydrogen $\mathrm{H}^{+}$and a negatively charged residue. They can also attach $\mathrm{H}^{+}$to form a positively charged complex on the basis of amino acid residues. Amino acids of the former type include, in particular, glutamine and asparagine; and amino acids of the latter type include histidine, lysine, and other amino acids [15]. As a result, water that surrounds an albumin macromolecule may receive some excess of hydrogens $\mathrm{H}^{+}$or, on the contrary, lose some amount of hydrogens $\mathrm{H}^{+}$. As a result, the $\mathrm{pH}$ of the aqueous albumin solution either decreases or increases, respectively. The magnitude of the effect depends on the temperature, the presence of impurity ions in water, and the concentration of albumin macromolecules.

Note also that, in histidine-type amino acids, the hydrogen $\mathrm{H}^{+}$interacts with the amino acid residues by means of electrostatic forces. In the aqueous environment of the near-surface layer of albumin, these forces become approximately $\varepsilon_{\mathrm{w}}$ times weaker, where $\varepsilon_{\mathrm{w}} \approx 80$ is the dielectric permittivity of water. That is why amino acids of this type dissociate. Inside albumin, the same amino acids remain intact because the dielectric permittivity is much lower here than in water. The attachment of hydrogens $\mathrm{H}^{+}$to the residues of such amino acid as histidine occurs due to the action of exchange forces that are responsible for the filling of the outer electron shell in the nitrogen atom. The final effect, i.e. the effective charge of albumin, depends on the number of amino acid residues of both types in the near-surface layer of the macromolecule, and this number can vary considerably with the temperature.

This conclusion is completely confirmed by experimental $\mathrm{pH}$ values for the aqueous albumin solution, represented as a function of the $\mathrm{pH}$ on the solution concentration for two different temperatures (Fig. 2). In Fig. 2, the concentration of albumin in the aqueous solutions is expressed as either the mass concentration $C$ or the volume fraction $\varphi$ of proteins in blood plasma. The volume fraction $\varphi$ is determined by the relation

$\varphi_{\mathrm{alb}}=\frac{4 \pi}{3} r_{\mathrm{eff}}^{3} \frac{\rho_{\mathrm{alb}}}{m_{\mathrm{alb}}}$,

ISSN 2071-0194. Ukr. J. Phys. 2020. Vol. 65, No. 9 
where $m_{\text {alb }}=M_{\text {alb }} \times 1.66 \times 10^{-24} \mathrm{~g}$ is the mass of albumin molecule, and $M_{\mathrm{alb}}$ is the atomic mass of albumin macromolecule (it is evaluated as $M_{\mathrm{alb}}=$ $=0.65 \times 10^{5}$ daltons). An important characteristic of the macromolecular solution is the the percolation threshold $\varphi_{\mathrm{p}}=0.23[16,17]$. At $\varphi_{\text {alb }}<\varphi_{\mathrm{p}}$, all albumin macromolecules in the aqueous solution can be regarded as isolated; otherwise, i.e. at $\varphi_{\text {alb }}>\varphi_{\mathrm{p}}$, as partially associated, i.e. there appear groups of bound albumin macromolecules in the system.

Blood plasma with the normal density is characterized by the parameter $\varphi \approx 0.23$, i.e. the volume fraction of albumin in blood plasma is close to the percolation threshold. The total relative volume of proteins in blood plasma is probably from $1 \frac{1}{2}$ to 2 times larger,

$\varphi_{\text {prot }}^{(u)} \approx 0.30 \div 0.40$.

Accordingly, one can see from Fig. 2 that a substantial modification in the character of the $\mathrm{pH}$ versus concentration dependence takes place in the interval $0.20<\varphi<0.23$, i.e. near the percolation threshold.

Another very important thing is that it is the albumin macromolecules that give the main contribution to the $\mathrm{pH}$ of blood plasma. Indeed, a comparison between the values of $\mathrm{pH}_{\mathrm{p}}-\mathrm{pH}_{\mathrm{w}}$ and $\mathrm{pH}_{\mathrm{alb}}$ at $\varphi_{\text {alb }} \approx 0.2$ brings us to the conclusion that

$\mathrm{pH}_{\mathrm{alb}} \approx \frac{2}{3}\left(\mathrm{pH}_{\mathrm{p}}-\mathrm{pH}_{\mathrm{w}}\right)$.

This relation between the pHs of blood plasma and the aqueous albumin solution testifies that a proportionality factor of $\frac{2}{3}$ almost exactly coincides with the relative fraction of albumin in blood plasma. This fact allows us to suppose that the index of acid-base balance in blood plasma is proportionally related to all its main components: albumin $(\approx 66 \%)$, globulins $(\approx 25 \%)$, fibrinogen $(1 \%)$, and so forth.

If the volume concentration of albumin macromolecules exceeds the percolation threshold, i.e. at $\varphi<\varphi_{\mathrm{p}} \approx 0.23$, the near-surface layers of neighbor macromolecules overlap. In this case, a significant amount of surface amino acids that detach and attach $\mathrm{H}^{+}$and belong to different macromolecules can form bonds with one another. In other words, they cease to exert influence on the $\mathrm{pH}$ of the aqueous albumin solution, which finds its manifestation in a weak dependence of the solution $\mathrm{pH}$ on the solution concentration (see Fig. 2). In real plasma, the effects of $\mathrm{H}^{+}$

ISSN 2071-0194. Ukr. J. Phys. 2020. Vol. 65, No. 9 deactivation induced by the overlapping of the surface layers of proteins play a not less important role.

We may assume that albumin in blood is responsible for certain mechanisms of homeostasis in the body, i.e. it helps to maintain the "equilibrium" state of an organism as an open system under the action of external factors $[18,19]$. From Fig. 2, one can see that, at a temperature of $37^{\circ} \mathrm{C}$, the variation of the albumin concentration in the solution results in disproportionately small changes of the $\mathrm{pH}$ index within the volume concentration interval from the percolation threshold to the maximum concentrations used in pharmacology. Thus, the study of the acid-base balance makes it possible to determine the limits of existence for that or another structural feature in the plasma biosolution. The interaction of proteins with water molecules and ions of dissociated impurities favors structural changes, especially when the acid-base balance changes.

\section{Peculiarities of Percolation Phase Transition in Aqueous Albumin Solutions}

The important role of percolation phenomena in the blood plasma of human beings and other mammals is not confined to the electrophysical properties of plasma, which were partially considered in the previous section. The electrostatic interaction between amino acid residues with different polarities in neighbor macromolecules is not negligibly small and can invoke appreciable changes in the density and viscosity of the system. An effect of this type was observed in work [17] (see Fig. 3).

In Fig. 3, the density of human blood plasma is exhibited as a function of the relative concentration $C / C_{0}$, which can be varied by adding the isotonic solution. One can see that there is a jump-like change in the plasma density at $\varphi_{*} \approx 0.2$. Such a behavior can be interpreted as a smeared phase transition in the system, which occurs at $\varphi_{*}$.

The change in the blood plasma density also leads to a variation in the average volume $v$ of proteins that enter the blood plasma. It is easy to see that

$\frac{\delta v}{v}=-\frac{\delta \rho}{\rho}$,

where $\delta \rho=0.003 \mathrm{~g} / \mathrm{cm}^{3}$ at $\varphi \approx 0.2$. From whence, it follows that the average volume of plasma protein - 


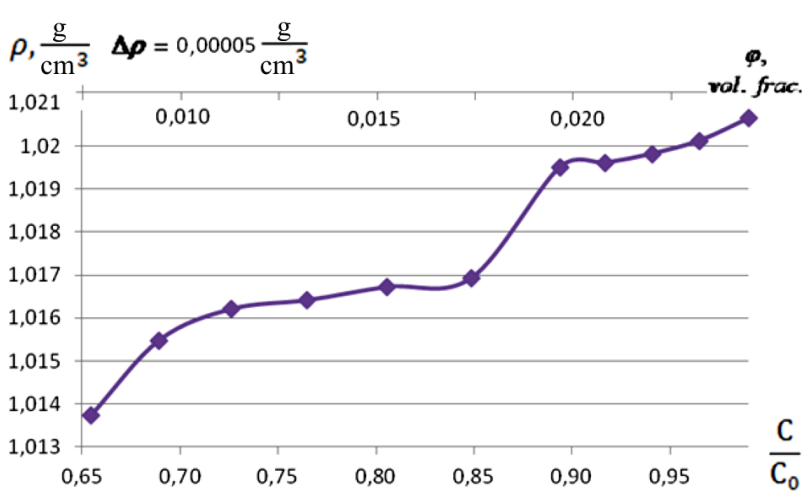

Fig. 3. Dependence of the density of the human blood plasma on the protein concentration in it. The protein concentration is reckoned in relative units: the lower axis corresponds to $C / C_{0}$, where $C_{0}$ is the average concentration of proteins in human blood [5], and the upper axis to the volume concentration

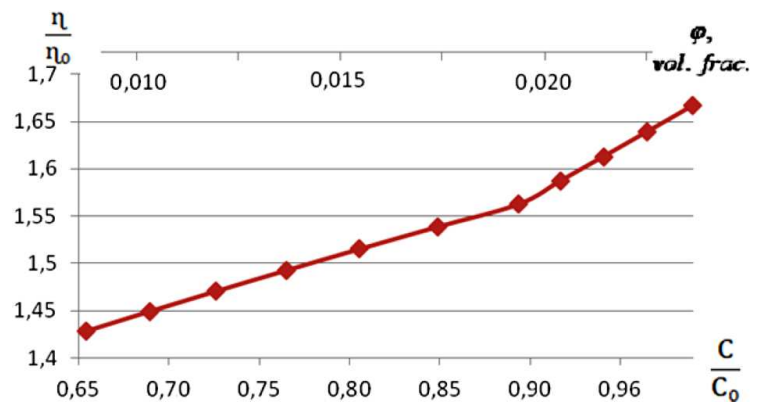

Fig. 4. Dependence of the relative viscosity of human blood plasma on the protein concentration in it $\eta_{0}$ is the shear viscosity of water). The lower axis corresponds to $C / C_{0}$, and the upper axis to the volume concentration

first of all, this is albumin - changes by a few percent, which is in good agreement with our assumption about the overlapping of the outer layers of neighbor macromolecules.

Taking the proteins as possessing a spherical, for simplicity, shape, the surface layer thickness can be evaluated by the formula

$$
\frac{\delta v}{v} \approx-\frac{S_{\text {overl }} \delta r_{\mathrm{p}}}{v} \Rightarrow-\frac{1}{4} \frac{r_{\mathrm{p}}}{r_{\mathrm{p}}} \delta \Omega=-0.003
$$

where $S_{\text {overl }}$ is the area of overlapping, and $\delta \Omega$ the corresponding solid angle. In this way, we find that

$\delta r_{\mathrm{p}} \approx \frac{0.01}{\delta \Omega} r_{\mathrm{p}}$
For $\delta r_{\mathrm{p}}$ to have an order of magnitude like the size of an amino acid residue, we must assume that

$\delta \Omega \approx 0.05 \div 0.1$

which corresponds to the overlapping "area"

$S_{\text {overl }} \approx r_{\mathrm{p}}^{2} \delta \Omega \approx 160 \div 320 \AA^{2}$.

Such a contact area between two adjacent macromolecules can contain no more than 5-7 different polar amino acid residues from each of two macromolecules. Therefore, the modeling of this contact with the help of two spheres does not resolve the problem of $\mathrm{pH}$ behavior to the right of the percolation transition point.

Hence, for the $\mathrm{pH}$ of solution to change slowly with the increase of protein concentration in this interval and for the $\mathrm{pH}$ increment with respect to that of water to be significantly smaller than the solution $\mathrm{pH}$ values to the left of the percolation transition point, a stronger assumption has to be made. We will assume that, to the right of the percolation transition point, albumin macromolecules, which look like a heart-shaped medallion, are superimposed onto one another by their quasiflat surfaces. In this configuration, two "medallions" interact with each other by means of (i) dispersion (van der Waals) forces and (ii) electrostatic forces arising between amino acid residues with different polarities. When such binary complexes - dimers - are formed, the effect of two albumin macromolecules on the $\mathrm{pH}$ of an aqueous solution will be almost the same as the effect induced by one macromolecule. It is not ruled out that a further growth of the albumin concentration in the solution will give rise to the formation of columns composed of trimers and tetramers, i.e. to the oligomerization process [21].

Quite unexpectedly, the relative concentration value near the percolation point completely coincides with empirical recommendations and medical protocols, according to which a blood substitute should not replace more than $10 \%$ of the blood volume. The existence of the percolation threshold also manifests itself in the behavior of the shear viscosity of blood plasma considered as a function of the relative concentration (see Fig. 4). Unlike the concentration dependence of the plasma density, only the slope of the concentration dependence of the dynamic shear viscosity changes at $C / C_{0} \approx 0.9$. At this concentration,

ISSN 2071-0194. Ukr. J. Phys. 2020. Vol. 65, No. 9 
a smeared phase transition takes place in plasma. It is this transition that is a physically substantiated prerequisite for the empirical medical protocol of blood transfusion, the essence of which consists in the existence of a maximum allowed amount for the blood substitute.

Note that there are two main reasons for the proteins to change their properties in aqueous solutions: (i) proteins change the character of their spatial arrangement and (ii) the internal structure of proteins also changes due to their interaction with one another through the aqueous environment. Let us briefly consider some specific features of both factors.

The albumin macromolecule in the dry state has the shape of a heart-like medallion [12]. In the aqueous medium, albumin macromolecules begin to "melt": their domains can fold or stretch depending on the temperature and the $\mathrm{pH}$ value. The structure of subdomains also undergoes a reconstruction. To some extent, the process of macromolecular "melting" in water is similar to structural transformations in water after ice melting. Immediately after the melting, the local structure of water remains to be ice-like, i.e. there appear clusters in the water bulk, the structure of which and the character of molecular thermal motion in which remain close to those in ice. The lifetime of such clusters is finite, which is their most characteristic difference from the ice-like state. It is clear that the decompaction of biomolecules should increase with the growing temperature.

The strongest influence of the internal reconstruction of protein macromolecules is experienced by the behavior of the heat capacity and dielectric permittivity of the system. Therefore, their further study can become decisive for our understanding of the processes running in the system.

\section{Macromolecules as an Indicator of a Phase Transition at $T=42{ }^{\circ} \mathrm{C}$}

In this section, we discuss the results of the study of effective hydrodynamic sizes of the polyvinyl alcohol (PVA) and human albumin macromolecules in their aqueous solutions [21,22]. The temperature and concentration dependences of the effective radius of those macromolecules were determined on the basis of experimental values obtained for the shear viscosity of corresponding solutions [23-25]. We compared the features of the aqueous environment influence on

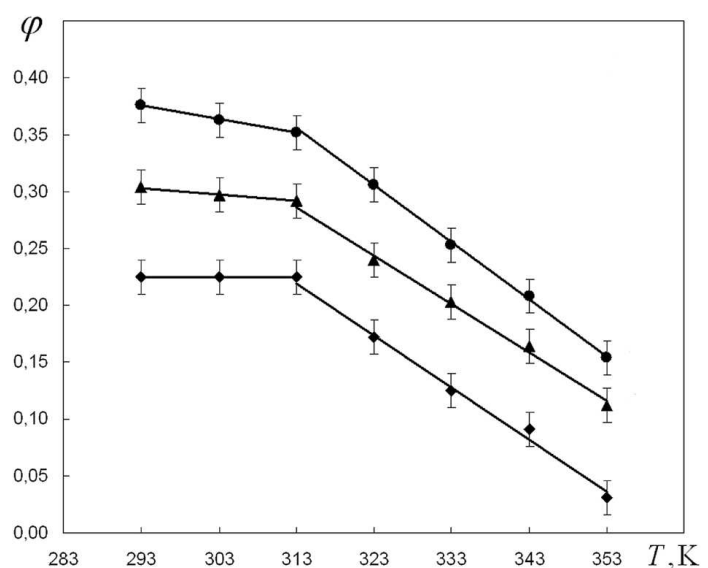

Fig. 5. Dependences of the PVA concentration on the temperature in aqueous PVA solutions at various constant radii of macromolecular coil: $59.65 \pm 0.05,61.35 \pm 0.05$, and $63.45 \pm$ $\pm 0.05 \AA$ (from top to bottom)

the PVA and albumin macromolecules, the internal structures of which are substantially different. Unlike the medallion-like structure of albumin, PVA macromolecules have a radially symmetric distribution of the substance with a core inside [21].

Figure 5 demonstrates the dependences of the PVA volume concentration on the temperature, provided that the radius of the PVA macromolecular coils remains constant. They are characteristic curves that make it possible to track the role of the effects of the interaction of macromolecules with the solvent and with one another, as well as the role of the molecular disordering, which increases with the growing temperature. For the first time, they were studied in work [21], being different from those exhibited in Fig. 5, because the PVA mass concentration was used as a parameter.

It is evident that the characteristic curves for the aqueous PVA solutions can be approximated by two pieces of straight lines with different slopes that intersect at the temperature $T_{D}=315 \pm 2 \mathrm{~K}$ [21]. As was shown in works $[6,26]$, pure water undergoes a dynamic phase transition at this temperature, at which the character of thermal motion of water molecules substantially changes. Hence, the size of PVA macromolecule in the aqueous solution plays the role of an indicator signaling that some modifications have occurred in water itself. The growth of PVA macromolecules in size with the increasing temperature is explained by the growth of fluctuations of the local 


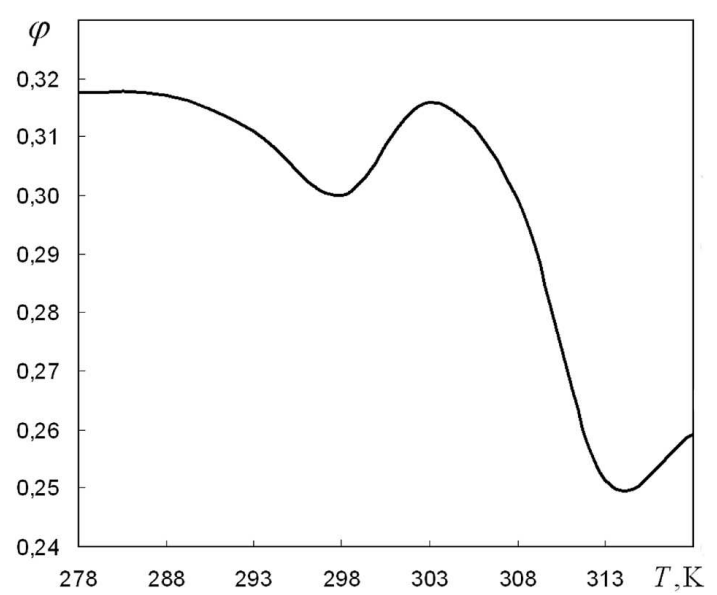

Fig. 6. Dependence of the albumin concentration on the temperature in aqueous albumin solutions with a fixed radius of albumin macromolecule $R_{\eta}=42.53 \pm 0.05 \AA$

density in the peripheral (near-surface) part of the macromolecular coil [21]. As a consequence, the core size $R_{\eta}$ either decreases or remains intact.

In the case of human albumin, the behavior of the characteristic curve that corresponds to the hydrodynamic radius $R_{D}=42.53 \pm 0.05 \AA$ is much more complicated (Fig. 6). Here, attention has to be focused, first of all, on the positions of the characteristic curve minima [22]. Their coordinates approximately coincide with the boundaries of existence for living matter, with the parameters of a deeper minimum being consistent with the water properties (the temperature at the minimum $T_{\min } \approx T_{D}$ ) and with the blood plasma properties (the volume fraction of albumin at the minimum $\varphi_{\min } \approx \varphi_{\mathrm{p}}$ ). These facts clearly emphasize the role of water properties in the formation of the most general properties of living organisms.

\section{Discussion of the Results Obtained}

The existence of a maximum temperature of $42{ }^{\circ} \mathrm{C}$ for human life was predicted in works $[6,8]$, which were devoted to the study of the temperature dependences of the properties of water and aqueous solutions of low-weight molecular liquids. Since water is the main building material of living organisms, an assumption was put forward that the denaturation of proteins at $42{ }^{\circ} \mathrm{C}$ and above is a result of the corresponding transformations in water, i.e. the protein denaturation is generated by a dynamic phase transition in water. In the presented work, we prove that the sizes of the al- bumin biomolecule and the molecule of the classical PVA polymer are also sensitive to changes occurring in water. This fact was also marked in works [25,27].

Note that the consistency of the results obtained for albumin and the model PVA polymer shows that water is the governing factor in the formation of the basic properties of biological solutions. By the way, water-free albumin can withstand much higher temperatures at the preparation of pharmaceuticals (85 ${ }^{\circ} \mathrm{C}$ and higher) without losing its biological activity. Particular attention in this work was paid to the analysis of the temperature and concentration dependences of the $\mathrm{pH}$ in water, blood, and aqueous albumin solutions.

The results obtained demonstrate that the temperature dependences of the $\mathrm{pH}$ in biological solutions and systems are mainly determined by the properties of water, whereas the concentration dependences by the specific features in the spatial arrangement of albumin macromolecules. An important assumption was made that, above the percolation threshold for the protein component, albumin macromolecules can form column-like dimers, trimers, and other analogous oligomers. It is albumin that makes the main contribution to the blood $\mathrm{pH}$ and can be considered as its stabilizer at certain concentrations of the protein component. The oligomerization of albumin macromolecules leads to a structural phase transition near the percolation threshold and is accompanied by a drastic change in the $\mathrm{pH}$ of the aqueous albumin solution, a quasijump of its density, and a change in the concentration dependence of the blood plasma shear viscosity.

1. P.E. Watson, I.D. Watson, R. D. Batt. Total body water volumes for adult males and females estimated from simple anthropometric measurements. Am. J. Clin. Nutr. 33, 27 (1980).

2. E.D. Giudice, P. Stefanini, A. Tedeschi, G. Vitiello. The interplay of biomolecules and water at the origin of the active behavior of living organisms. J. Phys.: Conf. Ser. 329, 012001 (2011).

3. I. Lorenzo, M. Serra-Prat, J.C. Yebenes. The role of water homeostasis in muscle function and frailty: A review. Nutrients 11, 1857, (2019).

4. M. Gekle, D. Singer. Warmehaushalt und Temperaturregulation. In Physiologie. Edited by H.-C. Pape, A. Kurtz, S. Silbernagl (Georg Thieme, 2014), p. 566 [ISBN: 978-313-796007-2].

5. W.F. Ganong. Review of Medical Physiology (McGrawHill, 2001).

ISSN 2071-0194. Ukr. J. Phys. 2020. Vol. 65, No. 9 
6. L.A. Bulavin, N.P. Malomuzh. Upper temperature limit for the existence of living matter. (Letter to the Editor). J. Mol. Liq. 124, 136 (2006).

7. A. Fisenko, N. Malomuzh. To what extent is water responsible for the maintenance of the life for warm-blooded organisms? Int. J. Mol. Sci. 10, 2383 (2009).

8. L.A. Bulavin. Dynamic phase transition in water as the most important factor in provoking protein denaturation in warm-blooded organisms. Fiz. Zhivogo 18, No. 2, 16 (2010) (in Russian).

9. N. Atamas, V.Y. Bardik, S. Komisarenko et al. Water dynamics and stability of major blood proteins at predenaturation stage. Atti Accad. Pelorit. Pericol. Cl. Sci. Fis. Mat. Nat. 97, S2, A16. (2019).

10. A.I. Fisenko, N.P. Malomuzh. The role of the H-bond network in the creation of the life-giving properties of water. J. Chem. Phys. 345, 164 (2008).

11. V. Nibali. New insights into the role of water in biological function: Studying solvated biomolecules using terahertz absorption spectroscopy in conjunction with molecular dynamics simulations. J. Am. Chem. Soc. 136, 12800 (2014).

12. X.M. He, D.C. Carter. Atomic structure and chemistry of human serum albumin. Nature 358, 209 (1992).

13. T.B. Rosenthal. The effect of temperature on the $\mathrm{pH}$ of blood and plasma in vitro. J. Biol. Chem. 173, 25 (1948).

14. CRC Handbook of Chemistry and Physics. Edited by R.C. Weast (CRC Press, 1972-1973).

15. T.T. Berezov, B.F. Korovkin. Biological Chemistry (Meditsyna, 1998) (in Russian).

16. R. Consiglio, D.R. Baker, G. Paul, H.E. Stanley. Continuum percolation thresholds for mixtures of spheres of different sizes. Physica A 319, 49 (2003).

17. N. Malomuzh, L. Bulavin, V. Gotsulskyi, A. Guslisty. Characteristic changes in the density and shear viscosity of human blood plasma with varying protein concentration. Ukr. J. Phys. 65, 151 (2020).

18. W.B. Cannon. The Wisdom of the Body (W.W. Norton, 1932).

19. T Peters Jr. All About Albumin: Biochemistry, Genetics, and Medical Applications (Academic Press, 1996).

20. R. Harada, N. Tochio, T. Kigawa, Y. Sugita, M. Feig. Reduced native state stability in crowded cellular environment due to protein-protein interactions. J. Am. Chem. Soc. 135, 3696 (2013).

21. O. Khorolskyi. Effective radii of macromolecules in dilute polyvinyl alcohol solutions. Ukr. J. Phys. 63, 144 (2018).

22. O. Khorolskyi. Calculation of the effective macromolecular radii of human serum albumin from the shear viscosity data for its aqueous solutions. Ukr. J. Phys. 64, 287 (2019).

23. N.P. Malomuzh, E.V. Orlov. Static shear viscosity of a bimodal suspension. Ukr. J. Phys. 50, 618 (2005).
24. E.V. Orlov. Shear viscosity of dispersions of particles with liquid shells. Colloid J. 72, 820 (2010).

25. O. Khorolskyi. The nature of viscosity of polyvinyl alcohol solutions in dimethyl sulfoxide and water. Ukr. J. Phys. 62, 858 (2018).

26. L.A. Bulavin, A.I. Fisenko, N.P. Malomuzh. Surprising properties of the kinematic shear viscosity of water. Chem. Phys. Lett. 453, 183 (2008).

27. A.N. Baranov, I.M. Vlasova, V.E. Mikrin, A.M. Saletskii Laser correlation spectroscopy of the processes of serum albumin denaturation. J. Appl. Spectrosc. 71, 911 (2004).

Received 13.04.20

Translated from Ukrainian by O.I. Voitenko

Л.А. Булавін, В.Я. Гоцулъсъкий,

М.П. Маломуж, А.І. Фісенко

ВИЗНАЧАЛЬНА РОЛЬ

ВОДИ У ФОРМУВАННІ ОСНОВНИХ

ВЛАСТИВОСТЕЙ ЖИВОЇ МАТЕРІЇ

$\mathrm{P}$ е $з$ ю м е

Досліджується зв'язок властивостей води з поведінкою водних розчинів базового білкового компоненту плазми крові людини - альбуміну. Експериментально досліджено залежності показника кислотно-лужного балансу рН водних розчинів альбуміну від його концентрації. Показано, що температурні залежності $\mathrm{pH}$ у біологічних розчинах визначаються властивостями води, а концентраційні - концентрацією білкового компонента. Саме альбуміном визначається основний внесок у рН крові та їі плазми, тому альбумін слід вважати чинником підтримування рівноважного значення рН. Показано, що концентраційні залежності густини та коефіцієнта зсувної в'язкості плазми крові людини свідчать про те, що їх найбільш характерні зміни відбуваються за концентрації білків, що відповідають порогу перколяції. Припускається, що біля порогу перколяції відбувається характерна димеризація макромолекул альбуміну, якій відповідає накладання серцеподібних медальйонів, якими зображуються просторові форми альбуміну, один на одного. Показано, що залежності ефективного радіуса макромолекул полівінілового спирту та альбуміну від температури та концентрації $є$ індикатором того, що вода відіграє визначальну роль у формуванні основних властивостей біорозчинів, зокрема вона є відповідальною за виникнення верхньої межі існування живої матерії $-42{ }^{\circ} \mathrm{C}$. Універсальний характер впливу води проявляється у тому, що її властивості відбиваються на поведінці і класичного полімеру ПВС, і біомолекул протеїну. 